\title{
Knowledge Management Strategies as a Competitive Advantage for Delivering Professional E-Government Services
}

\author{
*Mahdieh Sabaghpour, Azarian, Md. Nasiruzzaman, Md. Najibul Huq, Jamaludin Ibrahim \\ International Islamic University Malaysia, Malaysia \\ *mahdieh.sabaghpour@gmail.com
}

\begin{abstract}
Nowadays, organizations emphasize on practicing knowledge management to achieve higher level of efficiencies across delivering professional services, improving accountability, making informed decisions, enhancing partnerships, capturing the knowledge of an ageing workforce and improving overall performance. This paper investigates on a number of new generation Knowledge Management strategies to improve professional e-government service deliveries, which drives competitive advantage of successful horizontal and vertical interaction. Moreover, transformation of e-government to mgovernment (m-government platform) and social media analysis, knowledge sharing and personalization are four main KM strategies those specifically are targeted to attract youth generation to effectively use online governmental services, thus a proposed framework through this paper illustrates how successful integration of KM strategies and professional e-government services drive competitive advantage.
\end{abstract}

Keywords: Knowledge Management; Professional Services; Competitive Advantage; Service Delivery; Mgovernment; Social Media Analysis

\section{Introduction}

In this technological era, the government activities are increasingly upgraded to the web based. In order to achieve the certain goals, a good knowledge management strategy is needed. Therefore, knowledge management is becoming the critical factor for the success of e-government. The process of gaining the citizen's satisfaction and expectation especially the youth generation is very important to be well understood. A good knowledge management is all about getting the right knowledge, in the right place, at the right time (Vassilakis et al. 2007). The governments get benefited by adopting of knowledge management technologies to transform their traditional services into e- government services that can help them to achieve their goal to deliver their professional services to their citizen which focus on young generation. One of the key ingredients for the success of e- government services is the continuity of the availability, accessibility and application of appropriate governmental organization knowledge within egovernment systems, which can be accessed by the citizen. In the e-government environment, the knowledge management strategy plays a central role towards achieving economic competitiveness of the country. Knowledge management can transform knowledge which including people, processes, and technologies in order to increase and maintain a high service delivery to the citizen in these rapid change environments. A successful e-government system has the dual benefit of providing greater accessibility and efficiency for citizens while attempting to decrease the costs of service delivery for the government.

\section{The Importance of Knowledge Management in E-Government Service Deliveries}

Today, Knowledge Management is widely being accepted and applied through many organizations those willing for growth and winning a competitive advantage. Therefore, in order to understand the Knowledge Management Concept it is significant to realize the distinctions amongst data, Information and Knowledge as well as their relationship. It has been considered that the terms data and information are being used interchangeably with the term knowledge whereas in fact there are differences. Data is an actual value whereas, information is the processed value and the collection of data and information becomes knowledge similarly knowledge has a tendency to create its own context. The concept of KM need to be deeply realized and its benefits to the organization must be targeted. As KM is not a new trend and organizations used to utilize KM to make decisions, earlier, best practices will enhance using of KM more effectively and leads the organization to gain competitive advantage (Demaresh, 1997; Uriarte, 2008). Those organizations using KM practices without proper knowledge and awareness will fail to drive benefits from KM thus increasing awareness of using KM amongst individuals and organizations is required. This can lead organizations in the effective implementation of KM initiatives in organizations in 
search of increased performance and lastly to succeed. In today's global economic climate, organizations are seeking to become more operationally efficient, and more effective in achieving their objectives through increased productivity, higher quality, and more knowledge-driven work processes and practices. Citizens are demanding the highest possible value for public money and all organizations, especially public-sector organizations, are looking to significantly reduce costs, improve decision-making, and find innovative ways to develop and grow (An Oracle White Paper, 2011).

Pathak et al. (2008) indicates generally, the knowledge management is the process through which organizations generate value from their intellectual capital and knowledge-based assets. Usually, the value is obtained by finding what employees, partners and customers know, and sharing information with employees, departments and even with other companies, in order to find best practices. Knowledge management is important as a managerial tool, which promotes the creation of new knowledge and its sharing through the corporate values. Managers need to have a greater sense of invisible and intangible assets of people, featured in the minds and experiences of employees. Without these assets, companies are unequipped with vision and ability to predict the future (North et al, 2004). The using of knowledge management process increases the effectiveness of decision-making processes, as well as the level of operational efficiency, flexibility, commitment and involvement of employees. Knowledge management tools have increasingly been recognized by most governments in the world as strategic resources within the public sector. Some of the common challenges that affect the public sectors worldwide include enhancing efficiencies across all public agencies, improving accountability, making informed decisions, enhancing collaboration and strategic partnerships with stakeholders, capturing knowledge of an aging workforce as well as improving operational excellence (Parikh, 2001). It is also noted that knowledge management plays an imperative role in providing strategies and techniques to manage e-government content to make knowledge more usable and accessible (Davidson and Voss, 2002).

Main Knowledge Areas: People, processes, and technology are the three key elements of the Knowledge Management environment. KM focuses on people and organizational culture to stimulate and nurture the sharing and use of knowledge; on processes or methods to locate, create, capture and share knowledge; and on technology to store and make knowledge accessible and to allow people to work together without being together. People are the most important component, because managing knowledge depends upon people's willingness to share and reuse knowledge. (CIO Council, 2001). There are 3 key elements of Knowledge Management, those are people, processes and technology (Williams et al, 2011). The success of knowledge management initiatives depends upon people's motivation, their willingness, and their ability to share knowledge and use the knowledge of others. In general, there are two types of knowledge which are tacit knowledge and explicit knowledge. Tacit knowledge is that stored in the brain of a person. Explicit knowledge is that contained in documents or other forms of storage. Both types of knowledge can be produced as a result of interactions or innovations. Besides, Knowledge management involves a number of processes such as capturing, transferring, sharing, applying and creating a new knowledge within people or organizational entities. Therefore, the advancement in Information and communication technology (ICT) has affected the relation of people with governments through e-government (Williams et al, 2011). The involvement in the use of ICT in e-government helps to provide the efficiency and transparency of the process of providing information to the public as well as carry out administration activities. One of the examples to automate government functions and services is an interactive web interface which allows communication between government and its citizens through the web.

\section{New Generation of Knowledge Management Strategies}

Number of new Knowledge Management strategies have emerged recently, those lead organizational operations towards being more competitive by applying and practicing new KM strategies, in this regard, we have identified four main new KM strategies to be suggested to governmental agencies those seeking an opportunity in attracting youth to effectively use e-government services and that of course would carry the advantage of being first mover and creates more competitiveness. Therefore, this paper suggests four novel strategies of Knowledge Management:

Knowledge Sharing: There are several e-government services, which have purpose for sharing the knowledge. Firstly is a collaborative portal, which allow citizen login and participate in the e-government services will provide a detailed view and useful information. Secondly, in the knowledge sharing services category is e-education and online training workshop for youth generation, which provide educational materials through a website that they can access the knowledge. Next, are the Electronic Consultancy services, which mean the governments, providing the consultation for their citizens through online? The 
last services of e-government for sharing the knowledge are community binding which is as the platform to allow the knowledgeable citizen to share their knowledge to others.

Personalization / Customization: It has been believed that personalization / customization is a solution for information overload happening in recent decades and e-government services try to prescribe users of their e-services to make personalized access possible and enable self designing and implementation of web information systems hence personalization and profiling is being more encouraged trend amongst egovernment service users/ citizens.

Social Media Analysis: Social media analytics is the practice of gathering data from blogs and social media websites and analyzing that data to make business decisions. The social media analytics is to mine customer sentiment, which involves building a system to collect and examine opinions about the product and services made through social networking websites such as Facebook, blogger and twitter. The social media based services for e-government include providing forums, portals as well as the community radio. For the community radio, Kothmale Community Radio Internet Project is one of the most innovative egovernment pilot project example which help to test and demonstrate an access model that reduces the barriers and empowers marginalized communities in rural areas, enabling them to benefit from ICTs to expand their knowledge base and support their efforts to deal with their development problems (Santti, 2008).

M-Government: It is undeniably true that mobile platform had a dramatic and rapid adoptionwith technology in recent years this unparalleled advancement of mobile technologies has emerged the transformation of electronic government services (e-government) to m-government services and this is due to improving responsiveness of e-government and enhancement in service deliveries. This $\mathrm{m}$ government can utilize mobile platforms' location based services as an opportunity to grab an attention of younger generations of society to easily communicate with the government effectively through electronic mobile based services (Antovski and Gusev, 2005). Anincreasing variety of mobile apps, solutions and services, facilitate interactive communications and affects various aspects of education, daily life, health, employment, transportation, information and etc. therefore, the rapid transformation of e-government to m-government potentially drives competitive advantage over those are slow in adopting technologies with a mobile platform (Carrol, 2006).

\section{KM Strategies in E-Government Services Drive Competitive Advantage}

As mentioned above, the purpose of this paper is to demonstrate that effective use of Knowledge Management strategies in support of KM three main elements and their integration with e-government services professionalize service delivery and drive competitive advantage over all. A governmental company manages to deliver online services in order to enhance utilization of KM strategies, knowledge sharing, personalization, social media analysis and m-government. This leads companies to gain enormous e-loyalty over its users specifically youth generation those are more engaged with technological trends and growth.

Fig 1: A framework of the KM strategies supports competitive advantage in e-government services

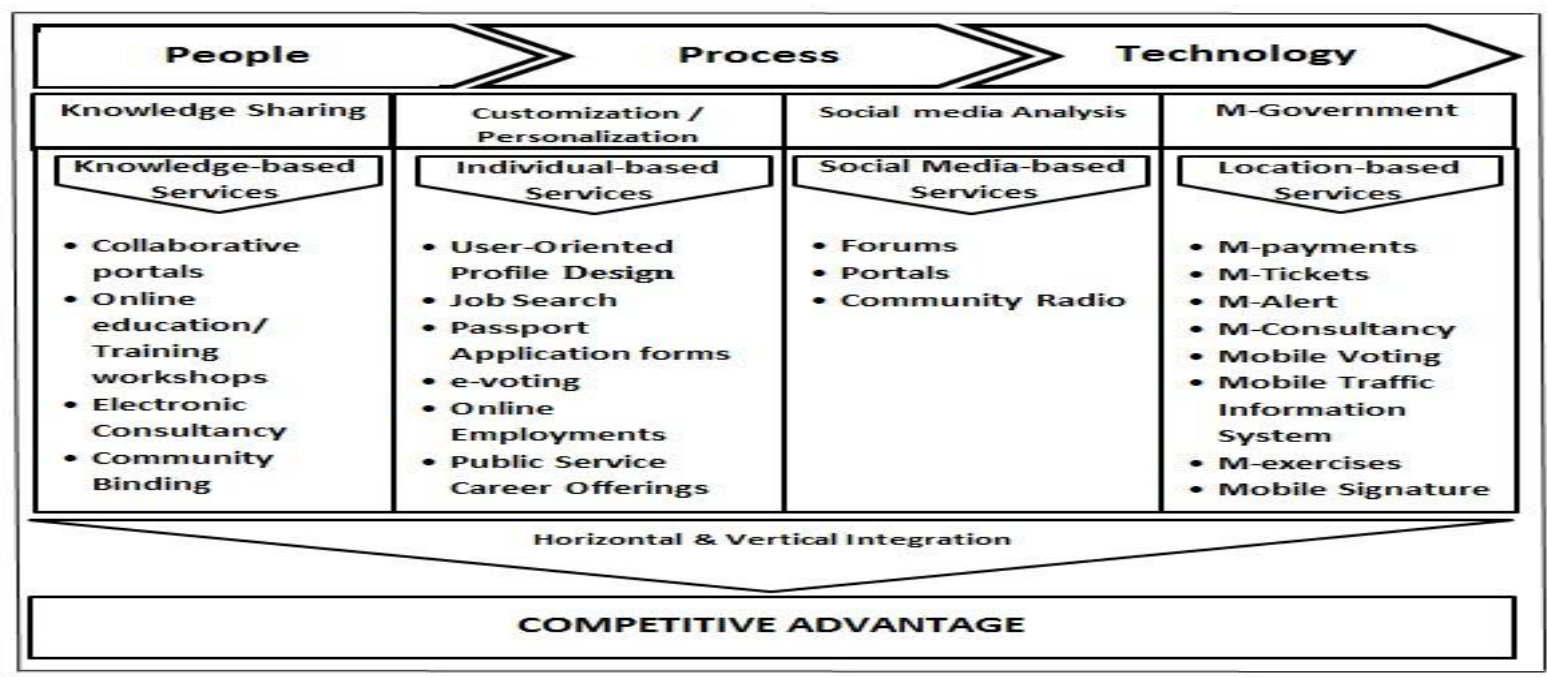




\section{Conclusion}

In conclusion, the globalization and enhancement of technology brought the huge changes in the way of delivering services, include in government which using the Knowledge management strategies and internet to deliver the services to the citizen. The approach to youth generation also had been done by providing some of the interactive services, which attract youth to use the government services. Egovernment services, had an impact on service delivery to achieve the competitive advantage. Nowadays, government should quickly adapt to the new dynamics of business and practice knowledge management strategies in order to improve efficiencies of service delivery. In order to achieve the competitive advantage for E- government, the key elements of Knowledge management which are people, process and technology, have to be aligned with the knowledge strategies.

\section{References}

An Oracle White Paper. (2011). Getting Knowledge management Right: Five best practices for a better $\begin{array}{llllll}\text { service } & \text { experience, } & \text { Retrieved } & 2 & \text { March } & 2013\end{array}$ http://www.oracle.com/us/products/applications/getting-knowledge-managt-right-wp1353041.pdf

Antovski, L. \& Gusev, M. (2005). M. Government Framework, paper presented at the Mobile Government Consortium International, Brighton, 10-12 July.

Asoh, D., Belardo, B. \& Neilson, R. (2002). KM: Challenges and opportunities for government in the new economy, Proceedings of the 35th International Conference on System Science.

Baccarini, D. (2008). The logical framework method for defining project success. Project Management Journal, 30, 25, 1999. PMI, A guide to the project management body of knowledge: Project Management Institute, 2008.

Carroll, J. (2006). What's in it for me? Taking m. government to the people, paper presented at the 19 th Bled eConference, Bled, 5 June.

Davidson, C. \& Voss, P. H. (2002). Knowledge Management: An introduction to creating competitive advantage from intellectual capital. Auckland New Zealand, Tandem Press.

Demaresh, M. (1997). Knowledge Management: An introduction Retrieved 28 March 2013 from http://www.noumenal.com/marc/km1.pdf

Drucker, P. (1993). Post-Capitalist Society. Harper Business Dynamics, New York 1993.

Dvir, D., Lipovetsky, S., Shenhar, A. \& Tishler, A. (1998). In search of project classification: a non-universal approach to project success factors. Research Policy, 27, 915-935, 1998.

European Commission, COM. (2010). The European eGovernment Action Plan 2011-2015 Harnessing ICT to promote smart, sustainable \& innovative government, European commission, Brussels, $\begin{array}{lllll}\text { Retrieved } & 7 & \text { April } & 2013 & \text { from }\end{array}$ lex.europa.eu/LexUriServ/LexUriServ.do?uri=COM:2010:0743:FIN:EN:pdf

Interchange of Data between Administrations. (2004). Multi-channel Delivery of E-government Services. $\begin{array}{llll}\text { Retrieved } & 11 & \text { March } & \text { from }\end{array}$ http://www.cisco.com/global/DE/pdfs/publicsector/ida_07_04.pdf

North, K., Reinhardtb, R. \& Schmidtc, A. (2004). The Benefit of Knowledge Management: some empirical

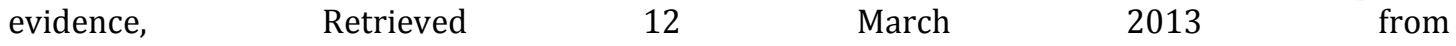
http://www2.warwick.ac.uk/fac/soc/wbs/conf/olkc/archive/oklc5/papers/a-8_north.pdf

OECD/International Telecommunication Union. (2011). M-Government: Mobile technologies for responsive governments and connected societies, OECD Publishing. Retrieved 2 April 2013 from http://dx.doi.org/10.1787/9789264118706-en

Pathak, R. D., Singh, G., Belwal, R., Naz, R. \& Smith, R. F. I. (2008). E-governance, Corruption and Public Service Delivery: A comparative study of Fiji and Ethiopia. JOAAG, 3(1).

Parikh, M. (2001). Knowledge management framework for high-tech research and development. Engineering Management Journal, 13(3), 27-33.

Petra, S. (2008). Developing Corporate Knowledge Management through Social Media, ESPOO, November 21, 2008. Retrieved 12 April 2013 from http://lib.tkk.fi/Dipl/2008/urn012879.pdf

Snellen, I. \& Thaens, M. (2008). From egovernment to $\mathrm{m}$. government: towards a new paradigm in public administration, working document, Erasmus University, Rotterdam. Retrieved 10 April 2013 from http://unpan1.un.org/intradoc/groups/public/documents/caimed/unpan028992.pdf

Tarek, E. (2007). Emerging Mobile Government Services: Strategies for Success, 20th Bled eConference, Slovenia Proceeding. 
Uriarte-Jr., F. A. (2008). Introduction to Knowledge Management, A Brief Introduction to the Basic Elements of Knowledge Management for Non-practitioners Interested in Understanding the Subject. ASEAN Foundation, Jakarta, Indonesia. ISBN No. 978 - 979 - 19684 - 0 - 9

Vassilakis, C., Lepouras, G. \& Halatsis, C. (2007). A Knowledge-Based Approach for Developing MultiChannel e-Government Services. Retrieved 14 March 2013 from http://smartgov.egov.gr/papers/multichannel.pdf

WLE. (2006). Benefit and Challenge of Knowledge Management. Retrieved 24 March 2013 from http://www.dlsu.edu.ph/conferences/etfp/papers/estacio.pdf

Williams D. E. \& Leask, J. (2011). People, Process, Technology Strategy for Enterprise 2.0, Retrieved 5 April 2013 from http://www.boozallen.com/media/file/People-Process-TechnologyEnterprise2.pdf 